\title{
Obesity and iron metabolism
}

\author{
Ewa Żekanowska*, Joanna Boinska, Paulina Giemza-Kucharska, Justyna Kwapisz \\ Department of Pathophysiology, Ludwik Rydygier Collegium Medicum in Bydgoszcz, Nicolaus Copernicus University in Toruń, Poland \\ *Corresponding author: zhemostazy@cm.umk.pl
}

\begin{abstract}
Obesity and overweight have become a global problem affecting not only high income countries but also developing countries. According to the World Health Organization (WHO) more than 1 billion adults are overweight and at least 300 million of them are obese. Experimental and clinical studies indicate that there is a relationship between iron metabolism and weight status. Iron deficiency is significantly more prevalent among obese individuals compared to non-obese ones. Adipose tissue produces many pro-inflammatory cytokines (interleukin-1, interleukin-6, tumor necrosis factor- $\alpha$ ) and adipokines (leptin, adiponectin, resistin) that influence iron homeostasis. According to recent studies, hepcidin, the main regulator of iron metabolism, can also be synthesized by the adipocytes. Development of iron deficiency among obese and overweight children has potentially harmful effects, which can lead to behavioral and learning problems as well as lowered resistance to infections. For this reason, screening for iron status among children with elevated BMI should be recommended.
\end{abstract}

Key words: obesity, iron metabolism, hepcidin

\section{Obesity as a global epidemic}

Obesity is a medical disorder in which excessive accumulation of body fat may cause serious health problems. Obesity increases the risk of type 2 diabetes, hypertension, heart disease, stroke, dyslipidemia, osteoarthritis, gynecological problems, sleep apnoea and respiratory problems (Kenchaiah et al., 2002; Wannamethee et al., 2005; Reijman et al., 2007). It is well documented that obese people are more susceptible to suffer some types of cancer, infections and a prolonged time of wound healing after surgery (Olsen et al., 2007; Guo and Dipietro, 2010).

Within the last three decades obesity has become a complex, chronic health problem. For this reason, the World Health Organization (WHO) consultation formally recognized a worldwide obesity epidemic in 1997 (World Health Organization, 2000; Caballero, 2007). For many years, obesity was considered a condition associated with high socioeconomic status. Nowadays, obesity and overweight are a problem affecting developing countries such as Mexico, China, Thailand and India (Ji and Working Group on Obesity in China (WGOC) 2007; GarcíaGarcía et al., 2009; Wang et al., 2009).

According to recent WHO data, more than 1 billion adults are overweight and at least 300 million of them are obese. Moreover, the prevalence of obesity among children and adolescents is increasing at an alarming rate. Data from the National Health and Nutrition Examination Survey (NHANES) revealed that since 1980, the prevalence of obesity among school children and adolescents in the United States has tripled (Ogden et al., 2006; Ogden et al., 2008).

Epidemiological data show that the percentage of overweight and obese children in Poland is also consistently increasing (Krawczyński et al., 2001). According to Sadowska and coworkers (2010), more than $6.67 \%$ of children between 4 and 6 years of age are obese, and $11.42 \%$ are overweight. According to another study in children between 7 and 10 years of age, $5.4 \%$ were diagnosed as obese, and $11.3 \%$ as overweight (BiałokozKalinowska et al., 2007). The prevalence of obesity and overweight among Polish adolescents (13-15 years of age) ranged from $2.2-4.5 \%$, and $8.8-11.4 \%$, respectively (Jodkowska et al., 2007). It is worth mentioning that the eating habits of children impact not only their physical and mental development, but often persists over their entire adult life (Rapacka et al., 2005). Obese children are at an increased risk of becoming obese adults.

Obesity in adults is measured in terms of a person's body mass index (BMI) which is determined both by 
weight and height. For adults, the cut-off points used are: $\mathrm{BMI}<18.5$ indicates that a person is underweight; BMI 18.5-24.9 is the desirable or healthy range; BMI 2529.9 is classified as overweight; and BMI $\geq 30$ is classified as obese. Because a child's BMI varies with age, different cut-off points are used to define overweight and obese children, depending on sex and age. Nutritional status is usually assessed according to the BMI values referenced by national BMI centile charts. American as well as many European researchers diagnose overweight and obesity in childhood, if the measured BMI value is $\geq 85$ centile (c) or $\geq 95$ c, respectively (Flodmark et al., 2004; Freedman et al., 2009). Recent study by Kułaga and coworkers conducted on Polish children and adolescents (OLAF, 2010) also defined the same criteria for the diagnosis of obesity and overweight (Kułaga et al., 2010).

\section{Adipose tissue as an endocrine organ}

Adipose tissue is currently recognized as an endocrine organ. It can contribute to the development of an inflammatory process by secreting pro-inflammatory cytokines and adipokines.Adipose tissue produces many cytokines and adipokines such as interleukin-6 (IL-6), interleukin-1 $\beta$ (IL-1 $\beta$ ), interleukin-8 (IL-8), tumor necrosis factor alpha (TNF-alpha), leptin, adiponectin, resistin, lipocalin-2, C-reactive protein (CRP), monocyte chemoattractant protein 1 (MCP-1), complement components, plasminogen activator inhibitor-1 (PAI-1). The most important adipokine synthesized by the white adipose tissue is leptin. Leptin consists of 166 amino acids and is a product of the human leptin gene $(L E P)$ located on chromosome 7q.31.3. (Kershaw and Flier, 2004; Arslan et al., 2010). Leptin influences food intake through a direct effect on the hypothalamus. Plasma leptin concentrations are highly correlated with BMI (Greenberg and Obin, 2006). Fat tissue is also a source of many hormones such as estrogens and proteins of the renin-angiotensin system. All these bioactive peptides, secreted from adipose tissue, can act either locally (autocrine/paracrine) or systemically (endocrine) (Kershaw and Flier, 2004; Greenberg and Obin, 2006; Arslan et al., 2010).

\section{Obesity and iron metabolism}

The relationship between obesity and iron deficiency has been investigated mainly in studies with children and adolescents. The results of the first epidemiological studies were published in the early 1960s (Wenzel et al., 1962; Seltzer and Mayer, 1963). The authors of these studies observed lower serum iron concentration in obese compared with normal weight adolescents (11-19 years of age). Most recent studies have shown similar results. A cross sectional study by Phinas-Hamiel and coworkers (2003), described a greater prevalence of iron deficiency (ID) in overweight and obese children and adolescents from Israel. In this study, ID was defined as iron concentration $<8 \mu \mathrm{mol} / \mathrm{l}$, and iron deficiency anemia (IDA) was defined as a hemoglobin level below 2 standard deviations (SDS) for age and gender. Subsequently, a large study confirmed those findings where it was demonstrated that overweight children were twice as likely to be iron deficient as normal weight children (Nead et al., 2004). Another study conducted among 740 school children of Teheran (Iran) also provided interesting results. The prevalence of iron deficiency increased with the subject's BMI (Moayeri et al., 2006). More recently, Sharma and coworkers (2009) examined 179 children - patients of the Children's Hospital of Eastern Ontario (CHEO), scheduled for minor, planned surgical procedures. Obesity was diagnosed in $16.7 \%$ of the subjects. This high BMI group had significantly lower serum iron levels and markedly higher CRP and soluble transferrin receptor levels (sTfR). Serum iron exhibited a significant correlation with both the BMI and CRP. Ferritin concentration, however, was similar in the group of obese as well as normal weight children (Sharma et al., 2009). A Study also has investigated the association between BMI and iron status in children from transition countries (Morocco and India) (Zimmermann et al., 2008). According to the study results, higher BMI $z$-score was a meaningful predictor of a weaker iron status. This observation is consistent with the results of previous studies in children from highly developed countries (Nead et al., 2004).

Richardson and coworkers (2009) conducted a prospective study to answer the question whether low iron status described in obesity is associated with the inflammation process. They evaluated high sensitivity CRP (hs$\mathrm{CRP}$ ), iron metabolism parameters (serum iron, ferritin, transferrin saturation) and weight status (BMI) in a group of 107 children and adolescents between 2-19 years of age. The BMI and serum iron were negatively correlated with hs-CRP, after age and gender adjustment. The final conclusion was that chronic inflammation due to obesity results in a low iron status. 
There are only a few clinical studies indicating that excess adiposity may negatively affect the iron status in the adult population. Among 406 adult volunteers it was observed that serum iron levels of obese subjects were significantly lower than those of normal weight subjects (Yanoff et al., 2007). Obese adults, in addition to having lower transferrin saturation and mean corpuscular volume (MCV), also had a significantly higher sTfR. These results indicate that adiposity is associated with an increased risk of iron deficiency among adults. A study conducted in a group of 50 obese (BMI $>30 \mathrm{~kg} / \mathrm{m} 2)$ and 50 non-obese postmenopausal women, found a significantly higher sTfR concentration in obese women. Moreover, positive correlations between BMI and STfR were detected in obese as well as non-obese women (Lecube et al., 2006). Lower levels of serum iron and transferrin saturation have been observed in obese adults compared to non-obese matched controls, with fat mass shown to be a significant negative predictor of serum iron concentration (Menzie et al., 2008). Inverse correlation between serum iron with BMI, waist circumference and fat mass in Hispanic women was also found (Chambers et al., 2006). It is also well documented that the prevalence of anemia as well as any kind of iron deficiency in patients scheduled for bariatric surgery is higher than in the general population (Yanoff et al., 2007; Menzie et al., 2008; Muńoz et al., 2009).

The pathomechanism of the hypoferremia of obesity is unclear. Iron deficiency in obese individuals may be a result of low iron intake (e.g. due to an unbalanced diet), reduced iron absorption in the small intestine, and greater iron requirements caused by a larger blood volume. In addition, obesity is associated with a chronic lowgrade inflammation state. For this reason, sequestration of iron through an inflammatory mediated mechanism can be one of the proposed causes of iron deficiency in obesity (Yanoff et al., 2007; Menzie et al., 2008).

\section{Hepcidin and iron deficiency in obesity}

Hepcidin is a recently identified peptide hormone. Human hepcidin gene (HAMP) is located on human chromosome $19 \mathrm{q} 13$ and encodes a precursor protein consisting of 84 amino acids. Hepcidin is released into the blood circulation as a peptide containing 20,22 or 25 amino acids. This protein is synthesized mainly in the liver, but also in the heart, pancreas, kidney, spleen and adipose tissue (Leong and Lönnerdal, 2004).
Hepcidin is a negative regulator of iron metabolism. It inhibits the absorption of iron in the small intestine and the release of recycled iron from macrophages. Thus, hepcidin affects the amount of iron available for erythropoiesis. There are many different factors that regulate hepcidin gene expression. The synthesis of hepcidin in the liver is increased by inflammation, infection, increased levels of serum iron and transferrin saturation. In contrast, hypoxia, erythropietic activity and mutations in the hepcidin gene (observed in hemochromatosis) decrease its expression (Kośla et al., 2004; Lipiński and Starzyński, 2004; Ganz and Nemeth, 2006). Interestingly, hepcidin concentrations in the hepatic and adipose tissues correlate with different iron status markers and inflammation indexes. The regulation of hepcidin gene expression and protein synthesis is probably tissue specific.

Hepcidin is an important hormone regulating iron metabolism during inflammation anemia (anemia of chronic disease). Many clinical studies indicate that there is a direct correlation between hepcidin gene expression and some cytokines such as IL- 6 and C-reactive protein in obesity. It has been reported that one of the adipokines - leptin, upregulates hepatic hepcidin gene expression. This suggests that increased leptin levels in obese patients could be a contributor to iron deficiency in obesity (Zafon et al., 2010). It is worth noting that a lower concentration of iron among obese patients might also be potentially related to a greater concentration of adipose hepcidin (Muńoz et al., 2009).

\section{Experimental and clinical studies indicating the link between hepcidin and anemia of obesity}

An experimental study that led to the commencement of a brand new field of investigations regarding iron deficiency anemia and obesity, was published in 2006 by Bekri and coworkers (2006). The authors of this study demonstrated for the first time, that hepcidin was expressed not only in the liver but also in the adipose tissue and was represented at both mRNA and protein levels. Hepcidin mRNA was higher in the adipose tissue of all obese patients, selected for bariatric surgery. Moreover, HAMP mRNA in the adipose tissue was positively correlated with inflammatory indexes (IL-6, CRP) and BMI. In contrast, HAMP expression in the liver was not related to CRP; however, liver $H A M P$ was positively correlated with serum transferrin saturation. Bekri and 
coworkers (2006) demonstrated that among obese patients, $68 \%$ had a low transferrin saturation ratio and $24 \%$ of them had anemia. The authors speculated that iron depletion can regulate hepatic HAMP expression rather than an adipose tissue-derived pool of hepcidin, as the latter was not correlated with trasferrin saturation.

Based on a study conducted on the $\mathrm{HuH} 7$ human hepatoma cells, it was demonstrated that leptin directly regulates hepatic hepcidin gene expression through the JAK2/STAT3 signaling pathway. Moreover, this effect was time- and dose-dependent (Chung et al., 2007).

Del Giudice and coworkers (2009) measured iron metabolism parameters, iron absorption, IL-6, leptin and hepcidin in a group of 60 obese children (BMI $>95$ centile), who took part in the weight loss program, and in 50 normal weight controls. They found a significantly lower serum iron and transferrin saturation in obese children compared with normal weight subjects, confirming the link between adiposity and low iron status. Obese children had a significantly higher hepcidin concentration, IL-6 and leptin levels when compared with normal weight controls. It is worth mentioning that serum hepcidin was positively correlated with leptin levels. These data appear to strengthen the hypothesis that obesity, as a low grade inflammation state, stimulates the production of many cytokines and adipokines such as IL- 6 and leptin. Leptin can up-regulate hepcidin synthesis by adipocytes. As a result, increased hepcidin levels may lead to poor iron status in obesity, by inhibiting iron absorption and restricting iron bio-availability.

Aeberli and coworkers (2009) also studied hepcidin concentration in parallel with iron intake, iron bioavailability, serum ferritin, sTfR, CRP and leptin in a group of 6-14 year old overweight children, compared with normal weight children. The prevalence of iron deficiency among overweight subjects was significantly higher than in normal weight controls ( $20 \%$ vs $6 \%$ ). Inflammatory markers (IL-6 and CRP) as well as hepcidin and leptin were significantly elevated in obese children. The authors of this study concluded that iron deficiency in obese children was caused by a hepcidin-mediated reduced iron absorption and/or an increased iron sequestration.

A study published in 2009 supported not only the relationships between prohepcicin (hepcidin prohormone), iron metabolism and obesity, but also their association with glucose metabolism disorders (FernandezReal et al., 2009).
Iron deficiency development among obese and overweight children has potentially harmful effects, which can lead to behavioral and learning problems as well as lowered resistance to infections. Due to this, screening for iron status among children with elevated BMI should be recommended.

\section{References}

Aeberli I., Hurrell R.F., Zimmermann M.B. (2009) Overweight children have higher circulating hepcidin concentrations and lower iron status but have dietary iron intakes and bioavailability comparable with normal weight children. Int. J. Obes. 33: 1111-1117.

Arslan N., Erdur B., Aydin A. (2010) Hormones and cytokines in childhood obesity. Indian Pediatr. 47: 829-839.

Bekri S., Gual P., Anty R., Luciani N., Dahman M., Ramesh B., Iannelli A., Staccini-Myx A., Casanova D., Ben Amor I. et al. (2006) Increased adipose tissue expression of hepcidin in severe obesity is independent from diabetes and NASH. Gastroenterology 131: 788-796.

Białokoz-Kalinowska I., Abramowicz P., Konstantynowicz J., Piotrowska-Jastrzębska J. (2007) Ocena stanu odżywienia dzieci $w$ wieku wczesnoszkolnym $z$ regionu Podlasia. Pediatr. Współcz. Gastroenterol. Hepatol. Żywienie Dziecka 9: 127-129.

Caballero B. (2007) The Global Epidemic of Obesity: An Review. Epidemiol. Rev. 29: 1-5.

Chambers E.C., Heshka S., Gallagher D., Wang J., Pi-Sunyer F.X., Pierson R.N. Jr. (2006) Serum iron and body fat distribution in a multiethnic cohort of adults living in New York City. J. Am. Diet. Assoc., 106: 680-684.

Chung B., Matak P., McKie A.T., Sharp P. (2007) Leptin regulates the expression of the iron regulatory hormone hepcidin in HuH7 human hepatoma cells. J. Nutr. 137: 2366-2370.

Del Giudice E.M., Santoro N., Amato A., Brienza C., Calabrò P., Wiegerinck E.T., Cirillo G., Tartaglione N., Grandone A., Swinkels D.W. et al. (2009) Hepcidin in obese children as a potential mediator of the association between obesity and iron deficiency. J. Clin. Endocrinol. Metab. 94: 5102-5127.

Fernandez-Real J.M., Equitani F., Moreno J.M., Manco M., Ortega F., Ricart W. (2009) Study of circulating prohepcidin in association with insulin sensitivity and changing iron stores. J. Clin. Endocrinol. Metab. 94: 982-988.

Flodmark C.E., Lissau I., Moreno L.A., Pietrobelli A., Widhalm K. (2004) New insights into the field of children and adolescents obesity: the European perspective. Int. J. Obes. Relat. Metab. Disord. 28: 1189-1196.

Freedman D.S., Wang J., Thornton J.C., Mei Z., Sopher A.B., Pierson R.N. Jr, Dietz W.H., Horlick M. (2009) Classification of body fatness by body mass index-for-age categories among children. Arch. Pediatr. Adolesc. Med. 163: 805-811. 
Ganz T., Nemeth E. (2006) Iron imports. IV. Hepcidin and regulation of body iron metabolism. Am. J. Physiol. Gastrointest Liver Physiol. 290: G199-203.

García-García E., De la Llata-Romero M., Kaufer-Horwitz M., Tusié-Luna M.T., Calzada-León R., Vázquez-Velázquez V., Barquera-Cervera S., Caballero-Romo Ade J., Orozco L., Velázquez-Fernández D., et al. (2009) Obesity and metabolic syndrome. A challenge for the Mexican Institutes of Health. Rev. Invest. Clin. 61: 337-346.

Greenberg A.S., Obin M.S. (2006) Obesity and the role of adipose tissue in inflammation and metabolism. Am. J. Clin. Nutr. 83 (suppl.): 461S-465S.

Guo S., Dipietro L.A. (2010) Factors affecting wound healing. J. Dent. Res. 89: 219-229.

Ji C.Y., Working Group on Obesity in China (WGOC) (2007) Report on childhood obesity in China (4) prevalence and trends of overweight and obesity in Chinese urban schoolage children and adolescents, 1985-2000. Biomed. Environ. Sci. 20: 1-10.

Jodkowska M., Tabak I., Oblacińska A. (2007) Ocena częstości występowania nadwagi i otyłości u młodzieży w wieku 1315 lat w Polsce przy zastosowaniu trzech różnych narzędzi badawczych. Przegl. Epidemiol. 61: 585-592.

Kenchaiah S., Evans J.C., Levy D., Wilson P.W., Benjamin E.J., Larson M.G., Kannel W.B., Vasan R.S. (2002) Obesity and the risk of heart failure. N. Engl. J. Med. 347: 305-313.

Kershaw E.E., Flier J.S. (2004) Adipose tissue as an endocrine organ. J. Clin. Endocrinol. Metab. 89: 2548-2556.

Kośla T., Cieślik C., Skibniewski M., Wrzesień R., Skibniewska E.M., Michalik P. (2004) Hepcydyna - hormon metabolizmu żelaza u człowieka i zwierząt. Część I. Rola hepcydyny we wchłanianiu zelaza $z$ przewodu pokarmowego i jego transporcie. Roczn. PZH. 55: 1-6.

Krawczyński M., Czarnecka A., Wysocka-Gryczka K., Krzyżaniak A., Walkowiak J. (2001) Otyłość u dzieci i młodzieży miasta Poznania. Aspekty etiopatogenetyczne, epidemiologiczne. Now. Lek. 70: 1110-1119.

Kułaga Z., Różdżyńska A., Palczewska I., Grajda A., Gurzkowska B., Napieralska E., Litwin M., Grupa Badaczy OLAF (2010) Siatki centylowe wysokości, masy ciała $i$ wskaźnika masy ciała dzieci i młodzieży w Polsce-wyniki badania OLAF. Standardy Medyczne/Pediatria 7: 690-700.

Lecube A., Carrera A., Losada E., Hernandez C., Simo R., Mesa J. (2006) Iron deficiency in obese postmenopausal women. Obesity 14: 1724-1730.

Leong W.I., Lönnerdal B. (2004) Hepcidin, the recently identified peptide that appears to regulate iron absorption. J. Nutr. 134: 1-4.

Lipiński R., Starzyński R.R. (2004) Regulacja ogólnoustrojowej homeostazy żelaza przez hepcydynę. Post. Hig. Med. Dosw. 58: 65-73.

Menzie C.M., Yanoff L.B., Denkinger B.I., McHugh T., Sebring N.G., Calis K.A., Yanovski J.A. (2008) Obesity-related hypoferremia is not explained by differences in reported intake of heme and nonheme iron or intake of dietary factors that can affect iron absorption. J. Am. Diet. Assoc. 108: $145-148$.
Moayeri H., Bidad K., Zadhoush S., Gholami N., Anari S. (2006) Increasing prevalence of iron deficiency in overweight and obese children and adolescents (Teheran Adolescent Obesity Study). Eur. J. Pediatr. 165: 813-814.

Muńoz M., Botella-Romero F., Gómez-Ramírez S., Campos A., García-Erce J.A. (2009) Iron deficiency and anaemia in bariatric surgical patients: causes, diagnosis and proper management. Nutr. Hosp. 24: 640-654.

Nead K.G., Halterman J.S., Kaczorowski J.M., Auinger P., Weitzman M. (2004) Overweight children and adolescents: a risk group for iron deficiency. Pediatrics 114: 104-108.

Ogden C.L., Carroll M.D., Curtin L.R., McDowell M.A., Tabak C.J., Flegal K.M. (2006) Prevalence of overweight and obesity in the United States, 1999-2004. JAMA. 295: 1549-1555.

Ogden C.L., Carroll M.D., Flegal K.M. (2008) High body mass index for age among US children and adolescents, 20032006. JAMA. 299: 2401-2405.

Olsen C.M., Green A.C., Whiteman D.C., Sadeghi S., Kolahdooz F., Webb P.M. (2007) Obesity and the risk of epithelial ovarian cancer: a systematic review and meta-analysis. Eur. J. Cancer. 43: 690-709.

Phinas-Hamiel O., Newfield R.S., Koren I., Agmon A., Lilos P., Phillip M. (2003) Greater prevalence of iron deficiency in overweight and obese children and adolescents. Int. J. Obes. 27: 416-418.

Rapacka E., Kowalczyk E., Błaszczyk J., Fijałkowski P. (2005) Nadmierna masa ciała problemem wieku rozwojowego. Żyw. Człow. Metab. 32(supl.1, cz.2): 776-779.

Reijman M., Pols H.A., Bergink A.P., Hazes J.M., Belo J.N., Lievense A.M., Bierma-Zeinstra S.M. (2007) Body mass index associated with onset and progression of osteoarthritis of the knee but not of the hip: the Rotterdam Study. Ann. Rheum. Dis. 66: 158-162.

Richardson M.W., Ang L., Visintainer P.F., Wittcopp C.A. (2009) The abnormal measures of iron homeostasis in pediatric obesity are associated with the inflammation of obesity. Int. J. Pediatr. Endocrinol. 2009: 713269.

Sadowska J., Radziszewska M., Krzymuska A. (2010) Evaluation of nutritional manner and nutritional status of pre-school children. Acta Sci. Pol., Technol. Aliment. 9: 105-115.

Seltzer C.C., Mayer J. (1963) Serum iron and iron-binding capacity in adolescents. II. Comparison of obese and nonobese subjects. Am. J. Clin. Nutr. 13: 354-361.

Sharma A.P., McKenna A.M., Lepage N., Nieuwenhuys E., Filler G. (2009) Relationships among serum iron, inflammation, and body mass index in children. Adv. Pediatr. 56 : 135-144.

Wang Y., Chen H.J., Shaikh S., Mathur P. (2009) Is obesity becoming a public health problem in India? Examine the shift from under- to overnutrition problems over time. Obes. Rev. 10: 456-474.

Wannamethee S.G., Shaper A.G., Walker M. (2005) Overweight and obesity and weight change in middle aged men: impact on cardiovascular disease and diabetes. J. Epidemiol. Commun. Health. 59: 134-139. 
Wenzel B.J., Stults H.B., Mayer J. (1962) Hypoferraemia in obese adolescents. Lancet 2: 327-328.

World Health Organization. 2000. Obesity: preventing and managing the global epidemic. Report of WHO Consultation. Geneva, Switzerland. World Health Organ Tech Rep Ser. 894: i-xii, 1-253.

Yanoff L.B., Menzie C.M., Denkinger B., Sebring N.G., McHugh T., Remaley A.T., Yanovski J.A. (2007) Inflammation and iron deficiency in the hypoferremia of obesity. Int. J. Obes. (Lond). 31: 1412-1419.
Zafon C., Lecube A., Simó R. (2010) Iron in obesity. An ancient micronutrient for a modern disease. Obes. Rev. 11: 322-328.

Zimmermann M.B., Zeder C., Muthayya S., Winichagoon P., Chaouki N., Aeberli I., Hurrell R.F. (2008) Adiposity in women and children from transition countries predicts decreased iron absorption, iron status and a reduced response to iron fortification. Int. J. Obes. 32: 1098-1104. 